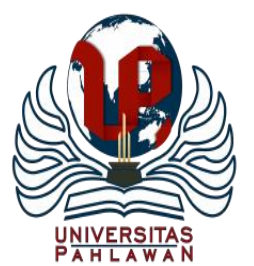

Jurnal Basicedu Volume 5 Nomor 1 Tahun 2021 Halaman 19- 29

JURNAL BASICEDU

Research \& Learning in Elementary Education

https://jbasic.org/index.php/basicedu

\title{
Perbedaan Kemampuan Pemahaman Konsep Matematika antara Pendekatan Realistic Mathematics Education dan Pendekatan Problem Solving di Sekolah Dasar
}

\author{
Amran $^{1}$, Khaidir Fadil ${ }^{2}$, Dadang Kurnia ${ }^{3}$ \\ Universitas Ibn Khaldun Bogor, Jawa Barat, Indonesia ${ }^{1,2}$ \\ Universitas Pakuan, Jawa Barat, Indonesia ${ }^{3}$ \\ E-mail: amran@uika-bogor.ac.id ${ }^{1}$ khaidir.fadil@uika-bogor.ac.id ${ }^{2}{\text { dadang_kurnia@unpak.ac.id }{ }^{3}}^{3}$
}

\begin{abstract}
Abstrak
Pemahaman konsep matematika anak SD masih rendah khususnya pada bidang geometri materi kubus dan balok, untuk itu diperlukan pendekatan pembelajaran yang efektif yaitu $R M E$ dan problem solving. Tujuan penelitian ini untuk mengetahui perbedaan pemahaman konsep matematika dengan menggunakan pendekatan RME dan pendekatan Problem Solving. Penelitian ini menggunakan pendekatan kuantitatif dengan kuasi eksperimen pada 138 siswa kelas V SD Negeri Pajeleran 01 Kecamatan Cibinong Kabupaten Bogor. Terdapat perbedaan pemahaman konsep matematika siswa dengan pendekatan $R M E$ dan pendekatan problem solving, siswa yang diberi perlakuan dengan menggunakan pendekatan $R M E$ lebih tinggi dibandingkan pendekatan problem solving. Perbedaan tersebut terlihat dari rata-rata pemahaman konsep yaitu $90 \%$ pada kelas eksperimen melalui pendekatan $R M E$, sedangkan pada kelas eksperimen yang menerapkan pendekatan Problem Solving rata-rata yang diperoleh yaitu $85 \%$. Penelitian ini hanya dilakukan pada siswa kelas V dengan materi kubus dan balok, dimana pada materi tersebut kemampuan pemahaman konsep siswa masih rendah. Hasil penelitian menunjukan rata-rata pada kelas pendekatan $R M E$ 74, pada kelas pendekatan Problem Solving 62 sedangkan pada kelas kontrol 35. Pengujian hipotesis dengan menggunakan uji $t$, diperoleh hasil $t_{\text {hitung }}(3,088)>t_{\text {tabel }}(1,99)$ sehingga Ho ditolak dan Ha diterima.
\end{abstract}

Kata kunci: pemahaman konsep; realistic mathematics education, problem solving

\section{Abstract}

Mathematical concept understanding of elementary school children is still low in the field of geometry of cubes and blocks, for that it requires memorable learning, namely RME and problem solving. The purpose of this study is to determine the differences in the use of mathematical concepts using RME and various problem solutions. This study used a quasi-quantitative experiment on 138 fifth grade students of SD Negeri Pajeleran 01, Cibinong Regency, Bogor Regency. Students, who's are given care use a higher RME than various problem solving. The difference is seen from the average attention to concept, which is $90 \%$ in the experimental class to $R M E$, while the experimental class that appears during problem solving the average obtained is $85 \%$. This investigation was only carried out on grade $V$ students with cube materials and blocks, at that time the students' ability to use concepts was still low. The results show oun that the average in the RME Approach class is 74, in the 62 problem-solving approach class while in the control class 35. Hypothesis testing using the $t$-test, the calculated results (3.088)> t-table (1.99) for Ho's rejected and Ha's request.

Keywords: concept understanding, realistic mathematics education, problem solving

Copyright (c) 2021 Amran, Khaidir Fadil, Dadang Kurnia

$\triangle$ Corresponding author

Address : Universitas Ibn Khaldun

Email : amran@uika-bogor.ac.id

ISSN 2580-3735 (Media Cetak)

Phone :

ISSN 2580-1147 (Media Online)

DOI: https://doi.org/10.31004/basicedu.v5i1.600 
DOI: https://doi.org/10.31004/basicedu.v5i1.600

\section{PENDAHULUAN}

Kegiatan pembelajaran pada hakikatnya harus mencakup aspek-aspek yang menunjang baik itu dari segi kompetensi pendidik dalam menyiapkan proses belajar mengajar, fasilitas belajar serta cara guru memahami karakteristik siswa agar mencapai tujuan pembelajaran yang diharapkan.

Guru dalam kegiatan belajar mengajar tidak hanya menyampaikan materi pembelajaran untuk siswa. Namun dalam kegiatan pembelajaran siswa dilibatkan secara fisik dan mental siswa sendiri. Pembelajaran matematika ialah bagian yang sangat penting dalam memahami konsep. Pemahaman konsep ialah salah satu kemampuan ataupun kecakapan matematika yang diharapkan bisa tercapai dalam proses pembelajaran matematika yaitu dengan menampilkan pemahaman konsep matematika yang sudah dipelajari (Wulan Yulianti, Dwi Sulistyaningsih, 2016). Pemahaman konsep yang baik akan didapatkan apabila proses kegiatan belajar yang dilakukan banyak melibatkan aktifitas siswa serta mengembangkan kemampuan dan kreativitas yang dimiliki oleh siswa (Jannah \& Rohmah, 2019). Tetapi dalam realitas kebiasaan guru dalam penerapan pembelajaran matematika masih cenderung memakai pembelajaran konvensional sehingga siswa merasa cepat jenuh serta guru tidak jarang menggunakan media pembelajaran ataupun model kooperatif yang baik dalam proses pembelajaran matematika sehingga pembelajaran jadi kurang menarik serta membosankan sehingga pembelajaran menjadi kurang efektif.

Kejenuhan dan rasa takut dalam proses pembelajaran matematika siswa berdampak pada kurangnya pemahaman siswa pada materi yang diajarkan, sehingga pemahaman konsep yang diharapkan belum tercapai yaitu dari hasil tes awal yang dilakukan peneliti yaitu terdapat banyak siswa nilainya di bawah KKM pada ulangan harian siswa dalam pembelajaran matematika materi kubus dan balok dari 138 siswa hanya 49 atau 35,5\% yang mencapai ketuntasan belajar sedangkan 89 siswa atau $64,5 \%$ siswa belum mencapai ketuntasan belajar sesuai dengan KKM. Selain itu nilai pada penilaian tengah semester (PTS) pada mata pelajaran matematika dari 138 siswa hanya 63 atau 45,6\% yang mencapai ketuntasan belajar sedangkan 75 siswa atau $54,4 \%$ siswa belum mencapai KKM untuk pelajaran Matematika pada siswa Kelas V SDN Pajeleran 01 yang telah ditentukan yaitu 65, maka dari itu siswa perlu mendapatkan pembelajaran yang bermakna dan efektif agar siswa lebih aktif dalam pembelajaran serta pemahaman konsep siswa semakin optimal dan hasilnya menjadi baik.

Kurangnya pemahaman konsep siswa dalam pelajaran matematika merupakan salah satu faktor yang ada dalam diri siswa. Siswa masih kesulitan menentukan langkah tepat menyelesaikan permasalahan yang diberikan sesuai dengan tahapan pemecahan masalah yang dinyatakan oleh Polya yang dimulai dari memahami masalah, merencanakan penyelesaian, menyelesaikan permasalahan, dan memeriksa kembali hasil yang diperoleh (Polya, 1981). Faktor yang ada dalam diri siswa dipengaruhi oleh faktor luar, dimana guru belum tepat dalam memberikan pendekatan untuk meningkatkan pemahaman konsep siswa pada pelajaran 
matematika khususnya materi tentang bangun ruang kubus dan balok (Nurkaeti, 2018).

Rendahnya kemampuan pemahaman siswa disebabkan oleh pendekatan pembelajaran yang digunakan di kelas lebih terpusat pada guru sehingga masih belum memfasilitasi siswa untuk mengembangkan kemampuan pemecahan masalah matematis. Kegiatan pembelajaran lebih menitikberatkan pada “chalk and talk”(A. Fauzan, E. Musdi, 2020).

Permasalahan rendahnya pemahaman konsep matematis ini diduga dapat diatasi dengan menerapkan pendekatan Realistic Mathematics Education (RME). Pendekatan ini menggunakan masalah realistik dalam belajar, siswa berkesempatan memahami permasalahan sebelum menyelesaikan, merencanakan, memilih strategi permasalahan yang tepat, sehingga dapat terpecahkan masalah kontekstual yang diberikan. Permasalahan realistic tidak harus selalu masalah yang ada pada kehidupan sehari-hari, tetapi dikatakan realistic jika bisa dibayangkan atau nyata dalam pikiran siswa (Mulyati, 2017). Pendekatan RME ini juga sebagai pembelajaran yang bersifat kontekstual karena bahan pembelajaran yang digunakan ialah bahan-bahan yang dekat, dikenal, mudah dicari dan menarik perhatian siswa (Lubis, Ariswoyo, \& Syahputra, 2020).

Melalui pendekatan RME siswa memiliki kesempatan untuk menemukan kembali dan merekonstruksi konsep matematika, sehingga memiliki pemahaman yang baik tentang konsep matematika dan membantu siswa memecahkan masalah (Susanti, 2017). Pembelajaran matematika realistik dikembangkan untuk memberikan satu cara untuk membuat kelas sebagai suatu komunitas belajar yang saling menghargai terhadap kemampuan masing-masing siswa (Rahman, 2017). Pendekatan RME ini berorientasikan pada penalaran siswa yang bersifat realistik sesuai dengan tuntutan kurikulum (Feni herlina, 2020).

Pembelajaran dengan pendekatan RME merupakan salah satu pendekatan pembelajaran matematika yang berorientasi pada aktivitas siswa, yang berarti matematika merupakan aktivitas manusia dan harus dihubungkan dalam konteks kehidupan sehari-hari siswa ke proses belajar yang berorientasi kehidupan nyata (Chisara, Hakim, \& Kartika, 2018). Pendekatan $R M E$ juga dapat memudahkan siswa dalam memahami setiap konsep matematika dan memahami konsep merupakan kemampuan dalam menjelaskan keterkaitan antarkonsep serta mampu menggunakan konsep maupun algoritma, secara luwes, akurat, efisien, dan tepat, dalam pemecahan masalah (Sari \& Yuniati, 2018).

Menurut wijaya dalam (Alamiah \& Afriansyah, 2018) RME merupakan suatu pendekatan dalam pembelajaran matematika di Belanda. Kata "realistik" sering disalah artikan sebagai "real-world", yaitu dunia nyata, namun sebenarnya RME ini berasal dari kehidupan sehari-hari anak, yang mudah untuk dipahami oleh siswa, dan terjangkau oleh imajinasi siswa, serta dapat dibayangkan sehingga mudah untuk mencari kemungkinan pemecahan permasalahanya dengan menggunakan kompetensi matematis yang telah dimiliki siswa.

Selain pendekatan RME, pemahaman konsep juga bisa ditingkatkan menggunakan 
penerapan pendekatan problem solving. Menurut (Saputra, Werdhiana, \& Darsikin, 2018) dalam penelitiannya terdapat pengaruh pendekatan problem solving terhadap pemahaman konsep siswa SMA Negeri 3 Palu. Sejalan dengan penelitian sebelumnya (Darmawan Mas'ud Rahman, Ettie Rukmigarsari, 2019) penelitiannya juga menyatakan terdapat pengaruh pendekatan problem solving terhadap pemahaman konsep matematika.

Menurut (Sopia, Sugiatno, \& Hartoyo, 2019) pendekatan pembelajaran problem solving merupakan suatu cara pembelajaran dengan menyajikan permasalahan supaya siswa mencari atau memecahkan masalah untuk mencapai tujuan pembelajaran. Selain itu pendekatan pembelajaran problem solving merupakan pendekatan dengan cara memecahkan suatu permasalahan dengan disajikan lebih awal supaya siswa terdorong untuk memecahkan permasalahan tersebut. Problem solving itu sekarang mulai ditinjau secara umum berdasarkan langkah-langkah pemecahan masalah terdiri dari siswa memahami masalah, membuat perencanaan, dan menyelesaikan masalah supaya pembelajaran lebih bermakna. (Tambunan, 2019).

Menurut (Suarman \& Gultom, 2018) Salah satu pendekatan pembelajaran yang dapat menjadikan siswa lebih aktif dan kreatif, dalam menyelesaikan permasalahan, menumbuhkan motivasi dan minat belajar siswa, adalah pendekatan problem solving. Sejalan dengan pendapat sebelumnya, pendekatan problem solving ialah suatu cara pembelajaran dengan mendorong siswa untuk memecahkan suatu permasalahan dalam rangka pencapaian tujuan pembelajaran.(Sopia et al., 2019). Problem solving merupakan salah satu tujuan pendidikan kurikulum matematika yaitu berpikir kritis dan menyelesaikan masalah. Problem solving ini sangat penting karena dalam proses kegiatan belajar mengajar maupun penyelesaiannya, siswa akan memperoleh pengalaman belajar menggunakan pengetahuan serta keterampilan yang sudah dimiliki untuk diterapkan pada proses pemecahan masalah.

Pada negara yang memiliki sistem pendidikan yang baik seperti Finlandia, Cina, Amerika dan Jepang kegiatan pembelajaran tersebut merupakan hal yang penting sebagai inti dari kegiatan belajar dan mengajar matematika di sekolah. Tujuan dalam pendekatan problem solving, peran guru lebih menekankan sebagai fasilitator dan motivator yang akan memberikan arahan siswa dalam membandingkan metode satu dengan yang lainnya, mencarikan solusi permasalahan dan seterusnya, sehingga dengan metode problem solving siswa dapat terlibat secara langsung kedalam pembelajaran yang akan memberikan kebermaknaan bagi pembelajaran siswa di kelas (Cahyo Dwi Andita, 2020).

Pembelajaran matematika menjadi lebih bermakna bagi siswa, dengan menerapkan pendekatan RME dan pendekatan pembelajaran problem solving dapat meningkatkan motivasi belajar siswa. Pendekatan ini perlu dilakukan karena guru matematika harus memahami cara bagaimana memberikan dorongan sehingga siswa menjadi tertarik belajar matematika dan lebih mudah memahami pelajaran matematika.

Berdasarkan hasil penelitian sebelumnya (Sari \& Yuniati, 2018), (Ulfah, Kowiyah, \& Fernandez, 2018) mengenai RME berkontribusi 
terhadap peningkatan pemahaman konsep dalam pembelajaran matematika. Selain RME, problem solving, juga berkontribusi dalam meningkatkan pemahaman konsep sebagaimana penelitian sebelumnya yang dilakukan oleh (Jannah \& Rohmah, 2019). Maka penelitian ini mencoba menganalisis perbedaan kedua pendekatan pembelajaran matematika tersebut dalam pemahaman konsep matematika siswa khusus sekolah dasar yang pernah dilakukan sebelumnya. Hasil penelitian ini mencoba membandingkan kedua pendekatan tersebut khusus dalam pemahaman konsep matematika.

\section{METODE}

Penelitian ini merupakan penelitian kuasi eksperimen dengan tujuan membandingkan pengaruh pendekatan RME dan Problem Solving dengan pembelajaran konvensional terhadap pemahaman konsep matematika. Variabel yang digunakan pada penelitian ini adalah pemahaman konsep sebagai variabel terikat, pendekatan RME dan Problem Solving sebagai variabel bebas.

Desain eksperimen yang dipilih adalah desain kelompok kontrol eksperimen klasikal. Tes awal (pretest) dan tes akhir (posttest) terhadap ketiga kelompok yang setara. Tes awal yang dilakukan sebelum perlakuan dan tes akhir dilakukan setelah siswa diberi perlakuan. Pada penelitian ini terdapat kelas eksperimen A (kelas yang mendapatkan perlakuan dengan menggunakan pendekatan Realistic Mathematics Education), kelas eksperimen B (kelas yang mendapatkan perlakuan dengan menggunakan pendekatan Pembelajaran Problem Solving) dan kelas kontrol C (kelas yang tidak mendapatkan perlakuan dengan pembelajaran konvensional).

Tabel 1. Desain Penelitian

\begin{tabular}{|c|c|c|c|c|}
\hline Sampel & Pretest & Treatment & Postest & Hasil \\
\hline $\mathrm{E}_{1}$ & $\mathrm{O}_{1}$ & $\mathrm{X}_{1}$ & $\mathrm{O}_{2}$ & $\mu_{1.1}$ \\
\hline $\mathrm{E}_{2}$ & $\mathrm{O}_{3}$ & $\mathrm{X}_{2}$ & $\mathrm{O}_{4}$ & $\mu_{1.2}$ \\
\hline $\mathrm{E}_{3}$ & $\mathrm{O}_{5}$ & $\mathrm{X}_{3}$ & $\mathrm{O}_{6}$ & $\mu_{1.3}$ \\
\hline
\end{tabular}

Populasi dalam penelitian ini adalah seluruh siswa kelas VA, VB dan VC di Sekolah Dasar Negeri Pajeleran 01 tahun ajaran 2019/2020 yang berjumlah 138 siswa dan pengumpulan data mengenai pemahaman konsep berupa tes uraian sebanyak 20 soal yang sebelumnya diuji cobakan untuk menguji validitas dan reliabilitas butir soal. Adapun pemahaman konsep diukur dengan skor melalui tes awal (pretest) dan tes akhir (postest).

Analisa data dilakukan pada hasil skor tes awal (pretest) dan tes akhir (postest). Kemudian dihitung menggunakan N-Gain, setelah itu uji normalitas dan uji homogenitas. Setelah data berdistribusi normal dan bersifat homogen dapat dilakukan uji hipotesis dengan uji t digunakan untuk mengetahui perbedaan pemahaman konsep siswa pada tiga kelas yang berbeda.

\section{HASIL DAN PEMBAHASAN}

Setelah dilakukan penelitian, kedua kelas sampel yang diberikan perlakuan dites akhir berupa tes kemampuan pemahaman konsep. Dari tes akhir diperoleh data sebagai berikut:

a. Perbedaan kemampuan pemahaman konsep matematika menggunakan pendekatan RME dengan pendekatan konvensional 
Education dan Pendekatan Problem Solving di Sekolah Dasar - Amran, Khaidir Fadil, Dadang Kurnia DOI: https://doi.org/10.31004/basicedu.v5i1.600

Tabel 2. Perbedaan Skor Rata-rata Pemahaman Konsep Matematika Menggunakan Pendekatan RME dan Pendekatan Konvensional

\begin{tabular}{|c|c|c|c|c|}
\hline \multirow{2}{*}{$\begin{array}{c}\text { Kelompok } \\
\text { Kelas }\end{array}$} & \multirow{2}{*}{$\mathbf{N}$} & \multicolumn{2}{|c|}{$\begin{array}{c}\text { Skor rata-rata } \\
\text { (Mean) }\end{array}$} & $\begin{array}{c}\text { Skor } \\
\text { rata- } \\
\text { rata } \\
(\mathbf{N}- \\
\text { Gain) }\end{array}$ \\
\hline $\begin{array}{c}\text { Realistic } \\
\text { Mathematics } \\
\text { Education }\end{array}$ & 46 & 49 & 86 & 74 \\
\hline Konvensional & 46 & 54 & 71 & 35 \\
\hline $\begin{array}{c}\text { Perbedaan } \\
\text { Pemahaman } \\
\text { konsep }\end{array}$ & & 1 & 15 & 39 \\
\hline
\end{tabular}

Berdasarkan data yang berhasil diperoleh perbedaan pemahaman konsep dilihat dari skor rata-rata antara RME (pretest 49 , postest 86,74 ) dan Konvensional (pretest 54, postest 71, 35) dapat dilihat pada histogram berikut ini.

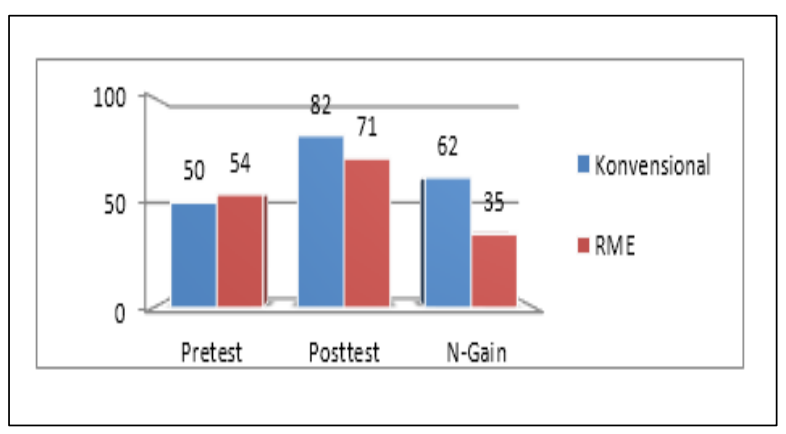

Gambar 1. Perbedaan Skor Rata-rata Pemahaman Konsep Matematika Menggunakan Pendekatan RME dan Pendekatan Konvensional

b. Perbedaan pemahaman konsep matematika antara menggunakan pendekatan Problem Solving dengan pendekatan Konvensional

Tabel 3. Perbedaan Skor Rata-rata Pemahaman Konsep Matematika Menggunakan Pendekatan Problem Solving dan Pendekatan Konvensional

\begin{tabular}{|c|c|c|c|}
\hline $\begin{array}{c}\text { Kelompok } \\
\text { Kelas }\end{array}$ & $\mathbf{N}$ & $\begin{array}{c}\text { Skor rata-rata } \\
\text { (Mean) }\end{array}$ & $\begin{array}{c}\text { rata- } \\
\text { rata } \\
(N- \\
\text { Gain })\end{array}$ \\
\hline
\end{tabular}

\begin{tabular}{|c|c|c|c|c|}
\hline & & Pretest & Posttest & \\
\hline $\begin{array}{c}\text { Problem } \\
\text { Solving }\end{array}$ & 46 & 50 & 82 & 62 \\
\hline Konvensional & 46 & 54 & 71 & 35 \\
\hline $\begin{array}{c}\text { Perbedaan } \\
\text { Pemahaman } \\
\text { konsep }\end{array}$ & & 4 & 11 & 27 \\
\hline
\end{tabular}

Berdasarkan data yang berhasil diperoleh perbedaan pemahaman konsep dilihat dari skor rata-rata antara Problem Solving (pretest 50, postest 82, 62) dan Konvensional (pretest 54, postest 71,35$)$ dapat dilihat pada histogram berikut ini.

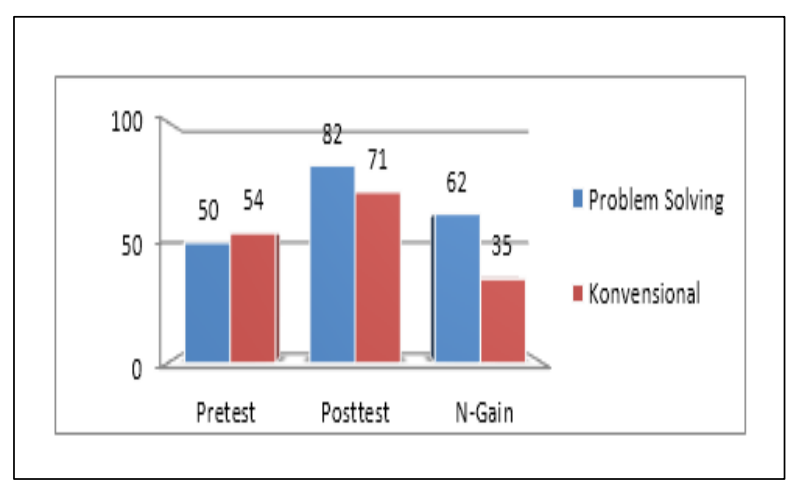

Gambar 2. Perbedaan skor rata-rata pemahaman konsep matematika menggunakan pendekatan problem solving dan pendekatan konvensional

c. Perbedaan pemahaman konsep matematika antara menggunakan pendekatan RME, pendekatan Problem Solving dan pendekatan Konvensional

Tabel 3. Rekapitulasi Nilai Pemahaman konsep

\begin{tabular}{|l|c|c|c|c|c|}
\multicolumn{2}{|c|}{ Matematika } \\
\hline $\begin{array}{l}\text { Kelompok } \\
\text { Kelas }\end{array}$ & $\mathbf{N}$ & \multicolumn{2}{|c|}{$\begin{array}{c}\text { Skor } \\
\text { rata-rata } \\
\text { (Mean) }\end{array}$} & $\begin{array}{c}\text { Rata- } \\
\text { rata } \\
(\boldsymbol{N}- \\
\text { Gain) }\end{array}$ & $\begin{array}{c}\text { Ketun } \\
\text { tasan }\end{array}$ \\
\cline { 3 - 6 } & Pretest & Posttest & \\
\hline $\begin{array}{l}\text { Pendekatan } \\
\text { RME }\end{array}$ & 46 & 49 & 86 & 74 & $90 \%$ \\
\hline $\begin{array}{l}\text { Pendekatan } \\
\text { Problem } \\
\text { Solving }\end{array}$ & 46 & 50 & 82 & 62 & $85 \%$ \\
\hline Konvensional & 46 & 54 & 71 & 35 & $70 \%$ \\
\hline
\end{tabular}


Berdasarkan tabel distribusi frekuensi di atas, maka grafik histogram rekapitulasi nilai pemahaman konsep matematika dapat dilihat pada gambar di bawah ini.

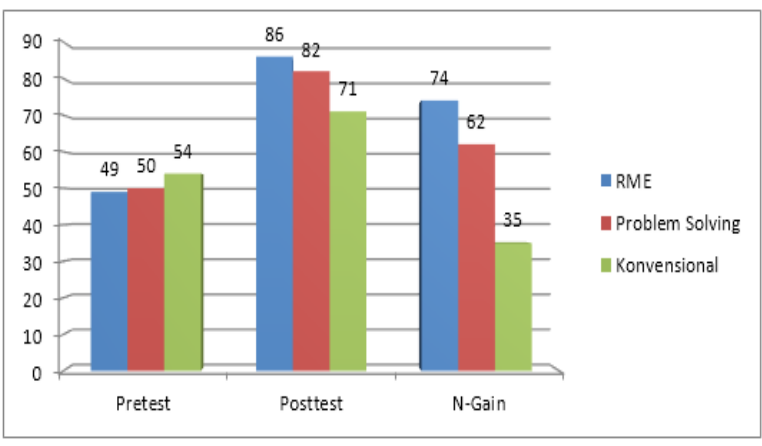

Gambar 3. Rekapitulasi Nilai Pemahaman konsep Matematika

Berdasarkan data di atas dapat dilihat bahwa nila $N$-Gain pada kelas V-A (kelompok eksperimen A) melalui pendekatan $R M E$ lebih besar dari pada kelas V-B (kelompok eksperimen B) melalui Pendekatan Problem Solving. Nilai $\mathrm{N}$ Gain pada kelompok eksperimen A melalui pendekatan $R M E$ yaitu sebesar 74 sedangkan kelompok eksperimen B melalui Pendekatan Problem Solving yaitu sebesar 62. Berdasarkan hal tersebut maka terdapat perbedaan pemahaman konsep matematika antara siswa yang melaksanakan pembelajaran menggunakan pendekatan RME dengan pendekatan Problem Solving.

Pada tahap berikutnya dilakukan perhitungan dengan uji t pada taraf signifikansi $\alpha / 2=0,05 / 2=0,025$. Setelah itu, dengan menggunakan tabel distribusi normal diperoleh nilai $\mathrm{t}_{\text {tabel }}=1,99$ dengan $\mathrm{dk}=90$, karena pengetesan dua arah sehingga daerah $\mathrm{H}_{0}$ berada pada interval $-1,99$ sampai 1,99 . Dari hasil perhitungan diperoleh nilai $t_{\text {hitung }}$ sebesar 3,088, Dimana jika : $\mathrm{H}_{0}$ diterima apabila nilai thitung pada interval -1,99 sampai 1,99 dan $\mathrm{H}_{0}$ ditolak apabila nilai $t_{\text {hitung }} \leq-1,99$ atau $\geq 1,99$. Dari uraian di atas dapat disimpulkan bahwa $\mathrm{H}_{0}$ ditolak karena thitung $(3,088) \geq t_{\text {tabel }}(1,99)$, maka $H_{a}$ diterima. Sehingga dari hasil penelitian ini diperoleh kesimpulan akhir bahwa secara keseluruhan pemahaman konsep matematika menggunakan pendekatan RME lebih tinggi dari pemahaman konsep matematika menggunakan pendekatan Problem Solving.

\section{Pembahasan}

Hasil penelitian ini terdapat perbedaan pemahaman konsep matematika pada kelas V-A menggunakan pendekatan RME, kelas V-B menggunakan pendekatan Problem Solving dan V-C menggunakan pembelajaran Konvensional pada materi bangun ruang kubus dan balok dapat dilihat dari hasil skor masing-masing kelas yaitu dimana kelas VA sebagai kelas eksperimen RME hasil skor rata-rata pada pretest adalah 49 , posttest 86 dan $N$-Gain 74 , kelas VB sebagai kelas eksperimen Problem Solving hasil skor rata-rata pada pretest adalah 50 , posttest 82 , dan $N$-Gain 62dan kelas VC sebagai kelas kontrol hasil skor rata-rata pada pretest adalah 54, posttest 71 dan $\mathrm{N}$-Gain 35. Dikarenakan pada pendekatan RME setiap siswa diberi kesempatan untuk memecahankan suatu soal cerita berupa balok dan kubus yang mengajak siswa untuk berpikir dan masuk dalam kehidupan sehari-hari. Sedangkan pendekatan Problem Solving siswa berpikir lebih 
lambat karena diberikan permasalahan untuk dipecahkan sendiri.

Uraian data hasil penelitian setelah dilakukan pengujian hipotesis, diperoleh hasil bahwa $\mathrm{H}_{0}$ ditolak sehingga hipotesis alternatif $\left(\mathrm{H}_{\mathrm{a}}\right)$ diterima, dan dari nilai yang diperoleh membuktikan bahwa terdapat perbedaan pemahaman konsep antara penerapan pendekatan RME dengan Pendekatan Problem Solving pada materi bangun ruang balok dan kubus.

Setelah diterimanya hipotesis alternatif, hasil penelitian juga diperkuat dengan data riil bahwa rata-rata pemahaman konsep matematika kelas V-A (eksperimen A) melalui pendekatan RME lebih tinggi daripada kelas V-B (eksperimen B) melalui pendekatan Problem Solving. Dengan demikian hasil pengujian hipotesis tersebut sekaligus membuktikan bahwa perbedaan pemahaman konsep pada setiap kelas bukan merupakan faktor kebetulan, tetapi disebabkan oleh adanya faktor perlakuan pada masing-masing kelas dan tentunya didukung oleh faktor-faktor penentu seperti kemampuan guru dalam mengelola pembelajaran, meliputi penggunaan pendekatan, media pembelajaran, kesesuaian dengan materi ajar, kesesuaian dengan karakteristik siswa, dan sebagainya.

Pendekatan RME dan Problem Solving bahwa inti dari pembelajarannya yaitu siswa dilibatkan dalam pembelajaran dengan menggunakan lingkungan sekitar dan bendabenda konkret sehingga siswa dapat berkolaborasi dan berdiskusi dengan teman sekelas sehingga mereka dapat menemukan caranya sendiri dan menggunakan matematika untuk menyelesaikan masalahnya baik secara individu maupun kelompok.

Pada saat pembelajaran melalui pendekatan RME siswa menjadi lebih termotivasi dalam belajar, dimana siswa lebih senang dan termotivasi karena pembelajaran menggunakan benda-benda yang nyata di kehidupan sehari-hari serta dengan diberikan suatu permasalahan untuk diselesaikan. Konteks dunia nyata yang digunakan sebagai sumber pembelajaran dapat berperan sebagai penguat kesan (a memory jogger) dan tidak mudah dilupakan, dan melatih keberanian siswa karena harus menjelaskan jawaban yang telah ditemukan dan berhasil dipecahkan, serta melatih siswa untuk terbiasa berpikir dan mengemukakan pendapat.

Setiap selesai pembelajaran guru juga melaksanakan evaluasi, dimana siswa diberi soal untuk dikerjakan masing-masing. Bagi siswa yang memperoleh nilai tertinggi serta kelompok yang mendapat skor tertinggi mendapatkan reward dari guru. Dengan pemberian reward siswa menjadi lebih bersemangat dalam belajar. Dari hasil penelitian diperoleh skor rata-rata kelas V-A melalui pendekatan RME ternyata menunjukkan hasil yang lebih tinggi dibandingkan dengan kelas V-B melalui pendekatan Problem Solving.

Pembahasan penelitian ini sudah diperkuat dengan teori dan penelitian yang relevan yaitu penelitian (Feni herlina, 2020) yang menyatakan terdapat pengaruh pendekatan RME terhadap hasil belajar sebesar $67 \%$ dan penelitian yang dilakukan (Ulfah et al., 2018) hasil penelitian yang diperoleh pada penerapan pendekatan RME lebih tinggi dari pendekatan Problem Solving. Hal tersebut terlihat dari perolehan hasil rata-rata yang 
diperoleh yaitu 88,33\% pada kelompok eksperimen 1 yang memperoleh pembelajaran melalui pendekatan RME, sedangkan pada kelompok eksperimen 2 yang memperoleh pembelajaran melalui pendekatan Problem Solving rata-rata yang diperoleh yaitu $69,58 \%$.

\section{SIMPULAN}

Berdasarkan hasil analisis data dan temuan penelitian yang diperoleh di lapangan selama menerapkan pendekatan Realistic Mathematics Education dan pendekatan Problem Solving di SD Negeri Pajeleran 01 Kecamatan Cibinong Kabupaten Bogor, dapat ditarik kesimpulan bahwa pemahaman konsep matematika yang menerapkan pendekatan Realistic Mathematics Education lebih tinggi dari pemahaman konsep yang menerapkan pendekatan Problem Solving dan Konvensional. Hal tersebut terlihat dari ratarata yang diperoleh yaitu $90 \%$ pada kelompok eksperimen 1 yang memperoleh pembelajaran melalui pendekatan RME, sedangkan pada kelompok eksperimen 2 yang memperoleh pembelajaran melalui pendekatan Problem Solving rata-rata yang diperoleh yaitu $85 \%$. Terdapat perbedaan antara pemahaman konsep kelas VA yang menggunakan pendekatan $R M E$, kelas VB yang menggunakan pendekatan Problem Solving dan kelas VC yang menggunkan pembelajaran Konvensional, hal ini dilihat dari nilai $N$-Gain pada kelompok eksperimen A menggunakan pendekatan $R M E$ yaitu sebesar 74 sedangkan kelompok eksperimen B menggunakan Pendekatan Problem Solving yaitu sebesar 62, kelompok kontrol $\mathrm{C}$ menggunakan pembelajaran Konvensional yaitu sebesar 35. jadi kedua pendekatan yang digunakan sebagai perlakuan berpengaruh positif terhadap pemahaman konsep matematika, serta hasil pengujian rata-rata yang signifikan yaitu $t_{\text {hitung }}(3,088) \geq \mathrm{t}_{\text {tabel }}(1,99)$ maka Ho ditolak dan Ha diterima.

\section{DAFTAR PUSTAKA}

A. Fauzan, E. Musdi, R. P. Y. (2020). The influence of realistic mathematics education (RME) approach in enhancing students' mathematical literacy skills. Journal of Physics: Conference Series, 1521(3), 9-12. https://doi.org/10.1088/1742$6596 / 1521 / 3 / 032052$

Alamiah, U. S., \& Afriansyah, E. A. (2018). Perbandingan Kemampuan Komunikasi Matematis Siswa Antara Yang Mendapatkan Model Pembelajaran Problem Based Learning Dengan Pendekatan Realistic Mathematics Education Dan Open-Ended. Mosharafa: Jurnal Pendidikan Matematika, 6(2), 207-216. https://doi.org/10.31980/mosharafa.v6i2.308

Cahyo Dwi Andita, T. (2020). Metode Problem Solving Untuk Meningkatkan Hasil Belajar Matematika di Sekolah Dasar. Jurnal Basicedu, 4(3), 541-550. https://doi.org/https://doi.org/10.31004/basic edu.v4i3.397

Chisara, C., Hakim, D. L., \& Kartika, H. (2018). Implementasi Pendekatan Realistic Mathematics Education (RME) dalam Pembelajaran Matematika. Journal Homepage, 65-72. Retrieved from http://journal.unsika.ac.id/index.php/sesioma dika

Darmawan Mas'ud Rahman, Ettie Rukmigarsari, S. N. H. (2019). Penerapan Pendekatan Problem Solving Dengan Model Think Talk Write Untuk Meningkatkan Kemampuan Penalaran Dan Pemahaman Konsep Pada Kubus Dan Balok. Jurnal Penelitian, Pendidikan, Dan Pembelajaran, 14(8), 47 55.

Feni herlina, T. (2020). Peningkatan Hasil Belajar Matematika Melalui Pembelajaran Matematika Realistik di Sekolah Dasar. 

DOI: https://doi.org/10.31004/basicedu.v5i1.600

Jurnal Basicedu, 4(4), 821-828. https://doi.org/10.31004/basicedu.v4i4.456

Jannah, A. N., \& Rohmah, S. N. (2019). Efektivitas Problem Solving dan Guided Inquiry terhadap Kemampuan Pemahaman Konsep pada Siswa SMP. Konferensi Nasional Penelitian Matematika Dan Pembelajarannya (KNPMP) IV.

Lubis, W. A., Ariswoyo, S., \& Syahputra, E. (2020). Kemampuan Pemecahan Masalah Matematika Melalui Pendekatan Pendidikan Matematika Realistik dan Pendekatan Penemuan Terbimbing Berbantuan Autograph. Edumatika: Jurnal Riset Pendidikan Matematika, 3(1), 1. https://doi.org/10.32939/ejrpm.v3i1.483

Mulyati, A. (2017). Pengaruh Pendekatan RME terhadap Kemampuan Pemecahan Masalah Siswa pada Materi Operasi Hitung Campuran di Kelas IV SD IT Adzkia I Padang. Jurnal Didaktik Matematika, 4(1), 90-97.

https://doi.org/10.24815/jdm.v4i1.8484

Nurkaeti, N. (2018). Polya'S Strategy: an Analysis of Mathematical Problem Solving Difficulty in 5Th Grade Elementary School. EduHumaniora | Jurnal Pendidikan Dasar Kampus Cibiru, 10(2), 140. https://doi.org/10.17509/eh.v10i2.10868

Polya, G. (1981). Mathematical Discovery: On Undestanding, Learning, and Teaching Problem Solving. New York: Jhon Wiley and Sons.

Rahman, A. A. (2017). Penerapan Pendekatan Realistic Mathematic Education ( Rme ) Pada Materi Statistika Untuk Meningkatkan Pemahaman Konsep Dan Prestasi. Genta Mulia, $\operatorname{VIII}(2), 1-12$.

Saputra, O., Werdhiana, I. K., \& Darsikin, D. (2018). Pengaruh Pendekatan Conceptual Problem Solving terhadap Problem Solving dan Pemahaman Konsep Siswa SMA Negeri 3 Palu. JPFT (Jurnal Pendidikan Fisika Tadulako Online), 6(2), 38. https://doi.org/10.22487/j25805924.2018.v6. i2.10437

Sari, A., \& Yuniati, S. (2018). Penerapan Pendekatan Realistic Mathematics Education (Rme) Terhadap Kemampuan
Pemahaman Konsep Matematis. Jurnal Cendekia: Jurnal Pendidikan Matematika, 2(2), 71-80. https://doi.org/10.31004/cendekia.v2i2.49

Sopia, N., Sugiatno, S., \& Hartoyo, A. (2019). Pengembangan Pemahaman Konseptual Dan Disposisi Matematis Siswa Melalui Penerapan Pendekatan Problem Solving Di Sma. J-PiMat: Jurnal Pendidikan Matematika, $\quad 1(1), \quad 11-20$. https://doi.org/10.31932/j-pimat.v1i1.405

Suarman, A., \& Gultom, S. P. (2018). Desain Model Pembelajaran Creative Problem Solving terhadap Kemampuan Pemahaman Konsep Mahasiswa FKIP UHN. Jurnal Penelitian Bidang Pendidikan, 24(2), 103110. Retrieved from https://jurnal.unimed.ac.id/2012/index.php/p enelitian/article/view/13949/11604

Susanti, S. (2017). Meningkatkan Kemampuan Pemecahan Masalah Matematis dan SelfEfficacy Siswa MTs Melalui Pendekatan Pendidikan Matematika Realistik. Suska Journal of Mathematics Education, 3(2), 92. https://doi.org/10.24014/sjme.v3i2.4148

Tambunan, H. (2019). The Effectiveness of the Problem Solving Strategy and the Scientific Approach to Students' Mathematical Capabilities in High Order Thinking Skills. International Electronic Journal of Mathematics Education, 14(2), 293-302. https://doi.org/10.29333/iejme/5715

Ulfah, S., Kowiyah, \& Fernandez, D. (2018). The Difference of Student Mathematical Concept Understanding Ability using Realistic Mathematic Education and Problem Solving. Jurnal Inovasi Pendidikan Dasar, 3(2), 1-6. Retrieved from http://jipd.uhamka.ac.id/index.php/jipd/articl e/view/48

Wulan Yulianti, Dwi Sulistyaningsih, V. D. M. (2016). Keefektifan Model Pembelajaran Kooperatif Tipe Preview Question Read Reflect Recite Review dengan Pendekatan Problem Solving terhadap Kemampuan Pemahaman Konsep Pada Materi Geometri Kelas X. Jurnal Karya Pendidikan Matematika, 3(1), 5-37. https://doi.org/https://doi.org/10.26714/jkpm $.3 .1 .2016 . \% 25 \mathrm{p}$ 
29 Perbedaan Kemampuan Pemahaman Konsep Matematika antara Pendekatan Realistic Mathematics Education dan Pendekatan Problem Solving di Sekolah Dasar - Amran, Khaidir Fadil, Dadang Kurnia DOI: https://doi.org/10.31004/basicedu.v5i1.600 